\title{
Rudolf Trümpy 1921-2009
}

\author{
Rudolf Trümpy, born 21 August 1921, Emeritus Professor of Geology at ETH Zürich and \\ President of IUGS between 1976 and 1980, passed away on 30 Jh January 2009 at his \\ home in Küsnacht, Switzerland.
}

Rudolf Trümpy, friendly known as Ruedi, was one of the most eminent and influential Alpine Geologists of the $20^{\text {th }}$ century. During his long and productive career he received numerous honours including the Wollaston Medal and the Penrose Medal for his pioneering work on paleogeography and nappe development in the Alps and his involvement in international activities culminating in the IUGS presidency (19761980). In 1978 he was elected a Foreign Associate of the United States National Academy of Sciences and in 1984 he became member of the French Academy of Sciences.

Rudolf Trümpy started his studies in 1940 at ETH Zürich where he graduated with a dissertation titled "Der Lias der Glarner Alpen". His field area was close to his birthplace Glarus, a small mountain city in the middle of the spectacular Helvetic Alps. His thesis turned out to be a most innovative work in Alpine paleogeography and in the reconstruction of the tectonic evolution of the northern "Helvetic" margin of the Alpine Tethys during the Early Jurassic. Ruedi Trümpy thought that he would become a petroleum geologist like his father, but his career took a different direction when he was offered a position at the University of Lausanne. There, he worked with Elie Gagnebin on stratigraphic and tectonic problems of the Valais region in western Switzerland and started his collaboration with a number of French colleagues, including Marcel Lemoine and Jacques Debelmas. While in Lausanne he wrote some remarkable early papers on facies trends, paleogeography and Alpine tectonics and he recognized facies similarities between the western and eastern Alps. At this time the working areas in the Swiss Alps were still regionally divided between the different Swiss universities but Trümpy, who moved from the Germanspeaking to the French-speaking part of Switzerland, was one of the few to be familiar with both eastern and western Alpine geology. While in Lausanne, Trümpy made another most important decision for his life: he got married with Marianne Landry who remained Ruedi's best companion throughout his

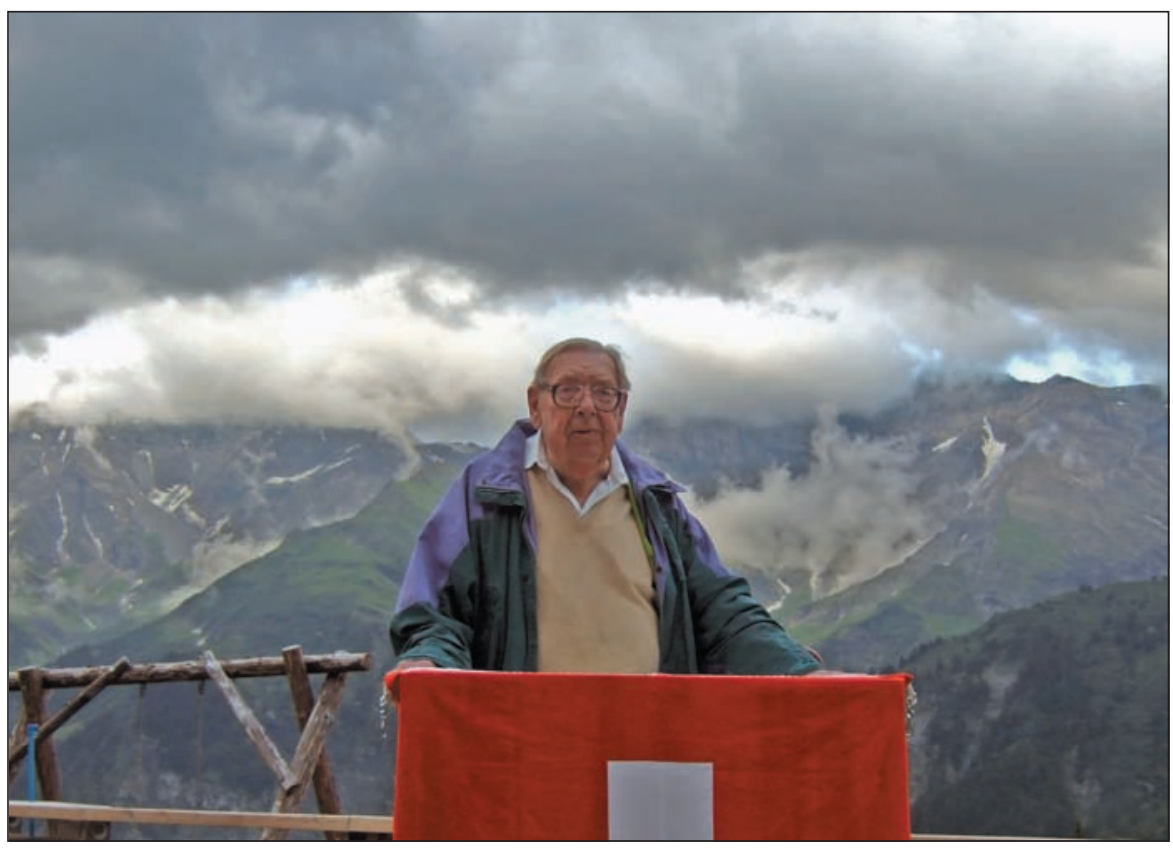

Rudolf Trümpy giving an improvised speech at the celebration party for the inscription of the Tectonic Arena Sardona in the UNESCO World Heritage list in 2008. This area has been recognised as a key site for the geological sciences since the 18th century. Studies of the clear exposure of the Glarus Overthrust in three dimensions have contributed substantially to the understanding of mountain-building tectonics. Photograph by Pierre Dezes

career. Marianne and Ruedi had two children, Barbara and Daniel.

In 1954 Rudolf Trümpy received a call from the ETH Zürich. He was appointed professor of stratigraphy at his home university and he stayed there until his retirement in 1986. As professor of stratigraphy he taught courses in historical geology, Alpine geology and sedimentology. Together with his many diploma and $\mathrm{PhD}$ students, he worked on various aspects of Alpine stratigraphy and geology. Ruedi Trümpy's early work culminated in a review paper on Alpine paleogeography and tectonics published in the Bulletin of the Geological Society of America. This 1960 paper on the "Paleotectonic evolution of the central and western Alps" made Rudolf Trümpy internationally known. The paper was written only a few years before the advent of plate tectonics and it still provides a very good overview on the state of knowledge of Alpine geology before plate tectonics revolutionized our view of mountain ranges.
In the early days of plate tectonics Rudolf Trümpy was not entirely convinced whether this new theory could explain his geological findings in the Alps. It took him several years until he could accept the new theory. Questions related to plate tectonics stimulated him to start a large project in Morocco and later in southern Spain in the early 1970's. Both projects are documented in a number of $\mathrm{PhD}$ theses which contributed to a better understanding of the geological history of the Betic Cordillera and the Moroccan Rif Mountains. In later years Rudolf Trümpy turned back to the eastern Alps in Switzerland where he continued to use a stratigraphic approach in his paleotectonic reconstructions of the Alps.

Rudolf Trümpy was not only an eminent researcher but also a gifted and dedicated teacher. He could fascinate students with his brilliant rhetoric and his unforgettable drawings on the blackboard. We students learned Alpine geology in the field on the numerous excursions into the Alps, to 
Provence or to Spain and Morocco. Ruedi Trümpy supervised a large number of diploma theses at the ETH and the University of Zürich. He took the time to visit all his students in the field. Teaching was never a burden for Ruedi Trümpy. He considered undergraduate teaching as the most noble work any professor could do at a university. Even during the sometimes difficult student protest years following 1968, Rudolf Trümpy was always ready for discussions on politics, on university structures, and on change of Earth science curricula with the protesting young student generation.

Ruedi Trümpy was a true intellectual with a broad cultural background and a strong interest in the history of science. He wrote essays on Goethe's geognostic ideas, on Alpine geology in the early $19^{\text {th }}$ century, and in one of his later papers he discussed why plate tectonics was not invented in the Alps. Last year he published, together with Andrea Westermann, a historian, a fascinating article about Albert Heim in the local journal "Zürcher Naturforschende Gesellschaft", a journal with a low impact factor. But it was the journal where Albert Heim published many of his famous papers on the Alps at the turn from the $19^{\text {th }}$ to the $20^{\text {th }}$ century. Trümpy was an excellent writer but he was even more famous for his brilliant talks. His eloquence impressed when he talked in German, in French or in English.

Ruedi Trümpy considered collaboration on the international level as essential for modern geology. Therefore it was not surprising that Trümpy accepted the election as President of IUGS in 1976. Ruedi Trümpy's career as an internationally outstanding scientist culminated when he opened the International Geological Congress in Paris in 1980. His book "An outline of the Geology of Switzerland" published on the occasion of the IGC in Paris provides an accurate overview of major geological units in Switzerland.

Trümpy's scientific achievements were honoured with numerous prestigious prizes and medals. Trümpy was of course proud of these many awards he received. But, as he told me recently, prizes were good for the ego but teaching and life-long contacts with former students provided long-lasting satisfaction.

Only four days before he died, we met for our monthly lunch in a restaurant near the ETH. We had our bottle of wine and our usual lively discussions on Alpine geology. Trümpy showed me his newest manuscript on Swiss geology in the Swiss army during the $2^{\text {nd }}$ world war. He asked me if I could find a student who could type this short manuscript. I found a young bachelor student -she typed the manuscript and she looked forward to meet famous Professor Trümpy the following weekend- too late. He passed away in the night between the $29^{\text {th }}$ and the $30^{\text {th }}$ of January. We have lost a brilliant and stimulating scientist, a man with a beautiful sense of humour, a good friend and for many, many of us an unforgettable teacher. Thank you, Ruedi, for all you have done for us.

Helmut Weissert

ETH Zürich

Switzerland

\section{Episodes is your window to the world. Subscribe today!}

\section{Episodes}

Name (please print)

Address

City

Country State/Province

Please begin my subscription from:

\begin{tabular}{rrrrr} 
March & June & Sept. & Dec. \\
Year & Year & Year & \\
\hline
\end{tabular}

To start your subscription, fill in this form and mail to:

\section{Episodes}

Geological Society of India

No.63, 12th Cross, Basappa Layout

Gavipuram P.O., P.O. Box No. 1922

Bangalore - 560 019, INDIA

Telefax: +91-080-26613352; Phone:+91-080-22422943

Email: episodes.journal@gmail.com
Payment may be made by:

- Checks (US \$ only) payable to:

'Geological Society of India A/C Episodes'

- Bank Transfer:

'Geological Society of India A/C Episodes'

Bank Name : Canara Bank, Hanumanthanagar Branch Bangalore - 560019

S.B. A/C No. : 0472101044517

Bank Code : 560015020

Swift Code : CNRBINBBLFD

Annual Subscription rate: US \$30 